DOI 10.31558/2519-2949.2020.3.11

УДК 327:330(8=134)

ORCID iD: https://orcid.org/0000-0002-1245-3459

Конопка Н. О., Національний університет «Острозька академія»

ORCID iD: https://orcid.org/0000-0003-2876-2093

Костів Б. Б., Національний університет "Острозька академія»

\title{
РИНОК ЕНЕРГОНОСЇ̈В КРАЇН ЛАТИНСЬКОЇ АМЕРИКИ В УМОВАХ ПАНДЕМІЇ: ЗАГРОЗИ, МЕХАНІЗМИ ЗАХИСТУ ТА ПОТЕНЦІЙНІ НАСЛІДКИ
}

Пандемія COVID-19 вплинула на усі країни світу, а ї̈ наслідки дають про себе знати не лише сьогодні, а й будуть помітними у довгостроковій перспективі. Стаття присвячена розгляду впливу коронавірусної кризи на ринок енергоносіїв країн Латинської Америки. В дослідженні визначено основні загрози, окреслено потенційні механізми захисту, зроблено спробу спрогнозувати подальший розвиток ситуації в енергетичній галузі в умовах кризи.

Мексика, аби протистояти наслідкам кризи, спричиненої коронавірусною хворобою, почала активно впроваджувати низку захисних механізмів (геджування, перенаправлення коштів державних трастових фондів тощо). Подібною є політика Аргентини, яка задля пом'якшення впливу кризи, запровадила указ про зобов'язання нафтовидобувних компаній підтримувати видобуток та інвестиџї на рівні 2019 р. Найбільш залежна від експорту нафти держава, Венесуела, опинилася перед загрозою гострого дефіциту. Паливо дозволили продавати приватним компаніям, що, своєю чергою, поставило крапку в державній монополії на енергоринку. Обвал иін на нафту засвідчив серйозні проблеми в економіці Колумбї̈, які можуть тривати кілька років.

Продовження чи повторне запровадження карантинних заходів не дарує надї на швидке відновлення попиту на нафту та нафтопродукти, що є загрозою зниженню інвестицій в регіон. Тому уряди держав змушені шукати фінансової підтримки у міжнародних організацій чи інших держав. Відзначено, щзо пандемія нанесла серйозний удар по краӥнах, щзо втратили потенщійні можливості й не змогли вийти на кращий економічний рівень. Крім того, виникли складнощі в успішній реалізації великих проєктів у сфері нафтовидобутку.

Автори дійшли висновку, що більшості краӥн регіону доведеться пристосовуватись до нових реалій $і$ як наслідок проводити структурні зміни у національних економіках. Оскільки закінчення пандемії COVID-19 у найближчий час є малоймовірним, а дотримання карантинних заходів все ж залишатиметься актуальним, то необхідно буде відшуковувати інші шляхи економічного розвитку, що не пов'язані із експортом енергоносіїв.

Ключові слова: ринок енергоносї̈в, Латинська Америка, COVID-19, Мексика, Аргентина, Венесуела, Колумбія, нафта, економіка, криза.

Постановка проблеми. Пандемія коронавірусу вплинула на всі країни світу як на рівні локальному, так і на глобальному, i це явище матиме складні та далекосяжні наслідки у багатьох сферах. Одним із уже очевидних результатів $є$ обвал ринку енергоносіїв, а найбільше нафти і нафтопродуктів. Це має різний вплив на країни, залежно від того чи є вони експортерами, чи ж залежать від імпорту цього ресурсу. Пропонуємо розглянути вплив та наслідки коронавірусної кризи на енергетичний сектор країн Латинської Америки та спробувати спрогнозувати, як ситуація розвиватиметься далі. Окрім того, не менш важливим чинником, який впливає на економіки держав регіону є залежність від економіки Китаю та наслідки впливу пандемії на економіку США. В умовах економічного шторму падіння цін на нафту-сирець, метали i мінерали призвело до падіння латиноамериканських фінансових та валютних ринків. До початку пандемії МВФ прогнозував ріст ВВП в регіоні на рівні 1,6\% до 2020 p. [4], однак, зважаючи на погіршення внутрішніх та зовнішніх умов, цього не сталося.

Мета дослідження. Необхідно проаналізувати енергетичний ринок країн Латинської Америки в умовах пандемії, визначити основні загрози, механізми захисту та потенційні наслідки для економічного, соціального та політичного становища держав досліджуваного регіону. 
Аналіз останніх публікацій. У роботі використано матеріали новинних порталів та аналітичних агенцій за березень-липень 2020 р., відколи пандемія набула глобального характеру. Зокрема важливим для нашого дослідження є огляд Організації економічного співробітництва та розвитку (Organisation for Economic Co-operation and Development) за травень 2020 р., у якому проаналізовано заходи вжиті урядами для зменшення та подолання кризи, що виникла внаслідок COVID-19. Для аналізу ситуації у Венесуелі дослідження опирається на публікацію агентства «Bloomberg», присвячену нещодавнім ініціативам та заходах країни у паливно-енергетичній галузі. Дані щодо експорту Венесуелою нафти-сирцю досліджено на основі публікації М. Паррага (Marianna Parraga) в «Reuters». Вплив пандемії та необхідність реформування економіки Колумбії для позбавлення ії залежності від експорту нафти розкрито в праці Хуана Родріго (Juan Rodrigo). Цікавою видається i аналітична розвідка H. Каннінгема (Nicholas Cunningham) опублікована в журналі Північноамериканського конгресу в Латинській Америці (The North American Congress on Latin America (NACLA)). Автор розглядає особливості впливу кризи на економіку Аргентини, аналізує механізми захисту впроваджені урядом А. Фернандеса та оцінює перспективи впровадження фрекінгу в енергетичному комплексі держави. Значну частину аналітичних та статистичних даних розміщено на інформаційному порталі MercoPress. Важливою для нашого дослідження стала інформація про обсяги експорту нафти світових держав, яка опублікована у звіті Центрального розвідувального управління США (CIA) «The World Factbook». У статті знайшли відображення результати попереднього дослідження Н. Конопки та Б. Костіва, присвяченого енергетичній залежності країн Центральної Америки і Карибського басейну.

Проте, перелічені публікації не розкривають цілісної картини становища енергетичного ринку держав регіону внаслідок коронавірусної кризи. У нашому дослідженні ми спробуємо комплексно та цілісно розглянути означену проблему.

Для початку варто визначити, які з країн в регіоні покладаються на власні запаси енергоносіїв та експортують їх, а які змушені покладатися на імпорт. У нашому дослідженні енергетичного виміру безпеки держав Центральної Америки і Карибського басейну ми визначили, що більшість острівних країн басейну Карибського моря в значній мірі залежні від імпорту енергоносіїв. Лише Барбадос, Куба та Тринідад і Тобаго покладаються на власний видобуток [1, с. 120]. Те саме справедливо і для Центральної Америки, де до відносно енергонезалежних належить лише Гватемала. Та якщо брати до уваги весь регіон Латинської Америки, ми побачимо, що деякі з країн належать до п'ятдесяти найбільших експортерів нафти у світі, це зокрема: Мексика, Венесуела, Бразилія, Колумбія, Еквадор та Аргентина [16]. Наслідки коливання цін на ринку нафти будуть різними для цих груп країн. Якщо для імпортозалежних держав падіння цін може мати позитивний вплив і пом'якшити наслідки економічної кризи спричиненої новітнім вірусом, то для експортерів це навпаки завдасть серйозного удару по економіці. Втім, цей удар буде не однаково важким для усіх держав. Все залежить від того, якою є частка експорту нафти і нафтопродуктів у національному валовому експорті, а також від того, які захисні механізми діють чи впроваджуються урядами, щоб уберегти національні економіки від обвалу цін.

За даними травня 2020 р. Організації економічного співробітництва та розвитку внаслідок пандемії Мексика, яка є одним з лідерів латиноамериканського енергетичного ринку, вже відчула наслідки кризи. Зокрема, у березні 2020 р. відбулося падіння мексиканського песо до рівня 2016 р. (перемоги Д. Трампа на президентських виборах); перервалися ланцюги постачання у зв'язку 3 впливом вірусу на економіку США та зменшенням туристичних потоків; 26 березня агентство Standard and Poor's (далі - S\&P) понизило кредитний рейтинг як для Мексики вцілому, так і для державної нафтової компанії Реmex, зокрема; 17 квітня Moody's понизило вартість облігацій Ретех, a агентство Fitch 15 квітня понизило кредитний рейтинг Мексики до рівня BBB*. 21 квітня поточного року Економічна комісія для Латинської Америки та Карибського басейну (CEPAL) спрогнозувала скорочення ВВП Мексики на 6,5\% у 2020 р. [4]

В такій складній ситуації Мексика змушена була впроваджувати додаткові заходи. Прикладом таких захисних механізмів можна назвати використання урядом геджування - страхування проти низьких цін, що гарантує країні можливість продавати нафту за наперед визначеною ціною. Така політика не вперше довела свою ефективність для Мексики. Так під час обвалу цін внаслідок світової фінансової кризи у 2009 р., Мексика отримала понад 5 млрд дол. США від продажу за геджугодами; у 2015 р. - 6,5 млрд дол. США, 2,7 млрд у 2016 р., коли Саудівська Аравія почала цінову війну [12]. Це не означає, що країна зовсім не відчуває наслідків цінових коливань, адже на підтримку такої політики державі за останні роки довелося витрачати близько 1 млрд дол. США 
щорічно. Однак, це дозволяє Мексиці підтримувати закладену у національному бюджеті ціну 49 дол. США за барель. Тому і сьогодні, попри важкі наслідки коронавірусної кризи для інших секторів економіки, Мексика може розраховувати на дохід від продажу нафти-сирцю і нафтопродуктів. Окрім того, мексиканський уряд відмінив та перенаправив більше 10 млрд дол. США із державних трастових фондів у Федеральне Казначейство. Ці кошти будуть використані для соціальних програм, відновлення економіки й кредитування, підтримки державної нафтової компанії Ретех та виплат державного боргу [4].

Схожу політику запровадила й Аргентина у травні цього року. Уряд країни оприлюднив указ, який зобов'язав нафтовидобувні компанії підтримувати видобуток та інвестиції на рівні 2019 р., а також встановив мінімальну ціну на внутрішньому ринку - 45 дол. США за барель сорту Medanito. Ціна буде варіюватися для інших сортів відповідно до якості. Така мінімальна ціна встановлюється до грудня 2020 р. у випадку, якщо тільки ціна нафти Brent не буде вищою за 45 дол. США за барель впродовж принаймні 10 днів підряд. Також указом скасовано податок на експорт нафти-сирцю та нафтопродуктів, який раніше складав 8\% від ціни, але знову ж таки доти, допоки ціна на Brent не підніметься вище 45 дол. США. Понад цю позначку податок розпочнуть поступово впроваджувати знову і відновлять повністю, якщо ціна виросте вище 60 дол. США. Уряд ввів штрафні санкції для компаній, які не будуть дотримуватися указу [3]. Таким чином, національні компанії до певної міри захищені від різких цінових коливань, і навіть попри скорочення попиту зможуть втриматися на ринку. У квітні 2020 р., незадовго після запровадження карантину в країні, державна компанія YPF змушена була скороти видобуток з більшості родовищ на $50 \%$, оскільки через падіння попиту на 70\% у перші дні карантину нафту не було де зберігати [21]. Травневий указ зобов'язує нафтопереробні компанії купувати сировину лише на внутрішньому ринку, що повинно принаймні до певної міри вирішити проблему з переповненими сховищами. Зважаючи, що Аргентина лише починає застосовувати такий протекціоністський механізм, очевидно, що втрати для економіки неминучі, оскільки сам механізм для країни новий і невідпрацьований, тому можна розраховувати лише на незначне пом'якшення наслідків кризи. I не варто забувати i те, що Аргентина і далі боргує величезні суми внаслідок фінансової кризи 2001 р. Виплати по боргах та їх розтермінування $\epsilon$ предметом переговорів вже майже два десятиліття. До початку пандемії адміністрація нового президента Альберто Фернандеса сподівалася завершити переговори з іноземними кредиторами про перегляд боргу до кінця березня поточного року, однак короновірусна криза ускладнила цей процес через неврегульованість фінансових ринків i сповільнення економічної активності. А відтак, Аргентина змушена була виплатити спочатку 250 млн дол. США, а згодом 500 млн дол. США для погашення платежів зовнішнього боргу [4]. В цьому складному економічному сценарії вплив COVID-19 на зовнішню торгівлю $є$ значним ще й тому, що КНР є другим за величиною експортним партнером Аргентини.

Венесуела, країна, яка найбільше залежить від експорту нафти, також починає змінювати свою політику в енергетичній сфері. На початку червня ц.р. було оголошено про підвищення цін на паливо. До цього громадяни країни користувалися субсидіями, що дозволяли купувати паливо ледь не задарма. Із початком коронавірусної кризи виробництво палива значно скоротилося і Венесуела постала перед загрозою гострого дефіциту. Зміни, запроваджені урядом, передбачають, що лише до 120 літрів на місяць можна купити за старою ціною, а решту - за міжнародною. Таким чином, уряд Н. Мадуро сподівається хоч якось покрити витрати на купівлю палива з Ірану, співпраця 3 яким розпочала налагоджуватися на тлі санкцій США. В травні ц.р. танкери з іранським паливом досягли берегів Венесуели, не зважаючи на тиск з боку США. Зрозуміло, що США прагнуть припинити співпрацю між двома «підсанкційними» державами. У минулому місяці представник Державного департаменту США заявив «Al Monitor», що тисне на енергетичні компанії, щоб вони утрималися від ведення бізнесу із нафтовим сектором Венесуели. Окрім того, в умовах спалаху коронавірусу, Іран надає і медичну допомогу цій латиноамериканській державі. Економічні зв'язки між Іраном та Венесуелою, ймовірно, продовжуватимуться, незважаючи на тиск з боку Вашингтону. Як іранські, так і венесуельські державні ЗМІ повідомляють, що поставки продовольства та нафтопродуктів будуть продовжуватися на регулярній основі [11].

Із веденням антикризових заходів паливо у Венесуелі зможуть продавати приватні компанії, що означає кінець державній монополії на енергоринку. 200 заправних станцій в країні віддано приватним компаніям, які зможуть продавати паливо за міжнародною ціною [17]. Однак не зрозуміло, за яким критерієм уряд обирав компанії, які отримали ліцензії. Цілком вірогідно, що ці приватні гравці міцно пов'язані із політичним режимом Н. Мадуро. Та й виникають сумніви, чи 
достатньо буде таких заходів для подолання політичної та соціальної кризи, яка триває у Венесуелі уже кілька років поспіль, а пандемія лише погіршила ситуацію. Криза також посилилась із впровадженням США санкцій проти державних установ і компаній, тому з відкриттям ринку для приватних гравців, Н. Мадуро сподівається хоча б частково обійти санкції. Однак, як тільки будуть доведені зв'язки між венесуельськими приватними компаніями та урядом Н. Мадуро, варто очікувати розширення санкційного списку.

$€$ й інші ризики відкриття ринку для приватних компаній. В аналізі агентства Bloomberg йдеться, що венесуельці вважають дешеве паливо одним із невід'ємних прав [22], і підняття цін раніше уже призводило до масових бунтів у Каракасі (1989 р.). Сьогодні це також може означати послаблення і до того нестійкої політичної позиції Н. Мадуро. Якщо аналізувати ситуацію під таким кутом, стає трохи зрозуміліше, чому США все ж не зупинили танкери з іранською нафтою, попри погрози. Якщо Венесуела купуватиме паливо в інших країнах, то змушена буде продавати його за вищими цінами, а це посилюватиме соціальну та політичну напругу і вцілому послаблюватиме режим. Таким чином, пандемія та американські санкції стають причиною серйозних зрушень в Боліваріанській республіці, i можуть мати не лише економічні, але й глибокі політичні наслідки. Зважаючи на дефіцит на внутрішньому ринку та дію санкцій, експорт венесуельської нафти впав до катастрофічно низьких показників. У травні ц.р. об'єм скоротився до 451,935 барелів на день, досягнувши мінімального значення періоду кінця 2002 - початку 2003 рp. [13] Експорт невпинно знижувався із впровадженням санкцій, у грудні минулого року він впав до 846,575 барелів на день [18], а із початком пандемії ситуація тільки погіршилася. Прогноз на подальші місяці теж був невтішним для уряду Н. Мадуро, потреба в реорганізації економіки постає все більш гостро, але розглянуті впровадження явно виглядають недостатніми для подолання кризи.

Із продовженням чи повторним запровадженням карантинних заходів у багатьох країнах не варто сподіватися на швидке відновлення попиту на нафту у світі, а отже і на прибутки від вкладених у видобуток коштів. Це загрожує суттєвому зниженню рівня інвестицій в регіоні. Зі скороченням інвестицій уряди змушені шукати фінансової підтримки у таких організацій як Світовий банк та Міжнародний валютний фонд або просити позики в інших держав. Водночас, через падіння прибутків після скорочення попиту, країни та компанії не можуть здійснювати виплати за попередніми позиками. Так бразильський штат Ріо-де-Жанейро постав перед загрозою втрати платоспроможності через неможливість здійснити виплати за домовленостями із американськими Dodge \& Cox та PIMCO. Ці інвестори мають право вимагати виплат у випадку, якщо ціна опускається нижче 40 дол. США за барель [20]. За прогнозами штат може втратити у цьому році до 3 млрд дол. США прибутків, в значній мірі і через падіння попиту на нафту. В такій ситуацій виплата 470 млн дол. США, які мають право вимагати американські інвестори, стане серйозним ударом для економіки штату, тому уряд змушений фактично покладатися на рішення інвесторів, які поки-що готові до переговорів. Вцілому для Бразилії коронавірусна криза несе потенційні загрози, враховуючи і той факт, що Китай $€$ головним торговельним партнером. В результаті COVID-19 бразильський фондовий ринок у 2020 р. впав більше ніж на 40\%. А бразильський реал щодо американського долара досяг мінімуму 1994 р. (рік запровадження валюти) [4].

Деякі країни уже змогли досягти домовленостей, які передбачають відтермінування виплати дивідендів, як наприклад Еквадор у квітні цього року. Та якщо криза триватиме, шукати компромісів стане важче, і падіння платоспроможності цілком може призвести до дефолту в окремих країнах, які надто сильно покладалися на прибутки від нафти. Весною 2020 p. ціна на марку West Texas Intermediate (WTI) впала на 24\% до 20,37 дол. США за барель. Агентство S\&P понизило довготерміновий $\mathrm{i}$ короткотерміновий кредитний рейтинг Еквадору із можливістю дефолту в найближчі місяці. Однак, уряду вдалося виплатити 320 млн. дол. США, щоб не втратити доступ до майбутніх джерел фінансування. 12 квітня поточного року Світовий банк спрогнозував, що економіка Еквадору скоротиться на 6\% у 2020 р. в порівнянні з прогнозом росту на 0,2\% жовтня 2019 p. [4] Згідно із рішенням Ради виконавчих директорів Світового банку Еквадор отримає 20 млн. дол. США для відновлення економіки [2], окрім того гроші виділять МВФ та КНР [4]. Окрім Еквадору, в травні поточного року КНР надала допомогу для боротьби з короновірусом Аргентині, Чилі, Колумбії та Венесуелі [10].

Пандемія та обвал цін на нафту показали і проблеми в економіці Колумбії, яка залежна від експорту нафти, що складає 39\% від загального експорту держави. Така ситуація може тривати протягом кількох років. Агентство Fitch в квітні поточного року понизило кредитний рейтинг Колумбії з рівня ВBВ до ВBВ-; водночас $\mathrm{S} \& \mathrm{P}$ у березні змінило прогноз із стабільного на негативний. 
«У випадку Колумбії це був фактор не лише пандемії, але й падіння цін на нафту», - заявив представник агентства Річард Френсіс [9]. Експерти, оцінюючи логістику та тривалість експортноімпортних операцій Колумбії, зауважили, що у порівнянні з іншими латиноамериканськими країнами, такими як: Перу, Мексика, Бразилія, Аргентина, Колумбія витрачає більше часу та зусиль для здійснення зовнішньої та внутрішньої торгівлі й комунікації. А відтак, для вирішення проблеми уряду варто активніше вводити в дію «цифрову економіку» (провадження Інтернет-мереж, використання блокчейна, безготівкові розрахунки і т.д.) [15], для відновлення економіки підчас та після пандемії й скоротити залежність від експорту нафти.

Щоб зрозуміти, як може розвиватися ситуація далі для країн-експортерів, економіка яких більшій чи меншій мірі залежить від продажу енергоносіїв, варто також простежити за окремими великими проєктами у сфері нафтовидобутку, зберігання і переробки нафти та нафтопродуктів. Яскравий приклад - проект “Морський лев" (Sea Lion) британських компаній Premier Oil та Rockhopper, які на початку року досягли домовленості з американсько-ізраїльським партнерським об'єднанням Navitas Petroleum про спільну розробку Фолклендських шельфових родовищ. I хоч Фолкленди лише географічно можна включити до досліджуваного регіону, та все ж проект можна розглядати в контексті саме окресленого регіону, в якому існує багато подібних проєктів (про один з них йтиметься далі в контексті Гайяни), а отже доля Sea Lion може повторитися і 3 подібними ініціативами. Загалом проект оцінюється у 1,8 млрд дол. США [8]. На початку року його бенефіціари доволі оптимістично оцінювали темпи розвитку проєкту, проте уже в квітні Rockhopper Exploration суттєво знизила активність в очікуванні більш сприятливої ринкової кон'юнктури. Було зупинено більшість операцій, які не пов'язані з фінансовими та фіскальними питаннями [7]. Ще через місяць Premier Oil зі свого боку вирішила призупинити проєкт, щоб мінімізувати фінансові втрати пов'язані 3 несприятливою ситуацією на ринку [14]. Звісно, це не означає, що проєкт повністю зупинено, та 3 огляду на те, що пандемія тільки набирає обертів, важко сказати, коли ринок буде готовий до подібних ініціатив. Зокрема до 2026 р. в регіоні планувалося ввести в експлуатацію десятки нових родовищ, серед найбільших це: Loma Campana (Аргентина, оцінюється в 17 млрд дол. США), Carcara (Бразилія, 3,5 млрд дол. США), Mero (Бразилія, 3 млрд дол. США), ВМ-С-33 (Бразилія, 3 млрд дол. США), Loran-Manatee (Венесуела, 2,1 млрд дол. США), Grand-Fuerte (Колумбія, 1 млрд дол. США), Inguazu (Болівія, 900 млн дол. США) [19]. Так, наприклад один із найбільших проєктів, Loma Campana, який вважається ключовим для Аргентини, уже в квітні цього року знизив темпи розвитку і обсяги видобутку через різке падіння попиту на нафту [6].

Якщо для згаданих вище країн пандемія означає удар по вже існуючій і добре налагодженій системі видобутку та збуту, то $є$ i ті, для яких нова криза - це, першою чергою, втрачені можливості i надії на вихід з того економічного становища, в якому вони перебували уже давно. Для однієї 3 найбідніших країн регіону Гайяни наступні п'ять років могли стати періодом небаченого економічного розвитку. Завдяки відкритим компанією Exxon Mobil у 2016 р. покладам нафти біля узбережжя цієї невеликої країни експерти прогнозували зростання економіки на $85 \%$, що могло б стати найвищим показником у світі [5]. Однак, при нинішньому стані енергетичного ринку принаймні у цьому році країні навряд чи вдасться досягти суттєвого росту. Країні ще варто провести чимало законодавчих змін, щоб мати можливість правильно використати гроші від нафтовидобутку, та навіть після затвердження відповідного законодавства прогнозованого розвитку може не статися. Ми не стверджуємо, що розвитку взагалі не буде, адже потреба в енергоносіях не зникне повністю навіть в умовах тривалої пандемії, та на $85 \%$ росту розраховувати не варто.

Багатьом країнам регіону доведеться пристосовуватися до нових економічних реалій та проводити структурні зміни національних економічних систем. Навіть якщо пандемія закінчиться найближчим часом, що малоймовірно, важко передбачити, коли попит на нафту відновиться до рівня попереднього року, якщо відновиться взагалі. Вірогідно, що багато заходів, які вводилися для боротьби з поширенням вірусу, залишаться в дії якщо не на офіційному рівні, то на рівні громадському, зокрема соціальне дистанціювання, робота та навчання в режимі онлайн, обмежений туризм можуть залишитися загальноприйнятою нормою ще принаймні на кілька років. За таких обставин необхідно буде шукати інших шляхів економічного розвитку, не пов'язаних з експортом енергоносіїв, і навіть такі країни як Мексика, які мають певний ступінь захисту від цінових коливань, змушені будуть зрозуміти, що варто зосередитися на розвитку більш збалансованої економічної системи. Не останню роль можуть відіграти кардинальні зміни та трансформація енергетичного сектору латиноамериканських держав щодо ширшого впровадження відновлювальної енергетики, що залишається предметом окремого дослідження. Окрім того, пандемія може ще більше відкрити ринки 
Латинської Америки для Китаю, поглибити залежність від китайських інвестицій, перетворити ресурсно багаті держави на «сировинний придаток» та ще більше усунути США від латиноамериканського енергетичного ринку, та регіону вцілому.

\section{Примітки:}

* Рейтинг Fitch рівня «ВBВ» повідомляє про поточно низькі очікування по кредитних ризиках. Здатність своєчасно погашати фінансові зобов'язання оцінюється як адекватна, однак негативні обставини і економічна кон'юнктура 3 більшою ймовірністю можуть знизити кредитоспроможність. Цей рівень рейтингу є найнижчим серед рейтингів інвестиційної категорії.

\section{Бібліографічний список:}

1. Конопка Н.О., Костів Б.Б. Проблеми енергетичної залежності держав Центральної Америки і Карибського басейну, Політичне життя. 2018. №2. С. 118-124. DOI 10.31558/2519-2949.2018.2.19

2. Стало відомо, на допомогу яким країнам підуть перші \$1,9 млрд Світового банку, Mind. URL: https://mind.ua/news/20209547-stalo-vidomo-na-dopomogu-yakim-krayinam-pidut-pershi-19-mlrd-svitovogobanku (дата звернення: 24.07.2020)

3. Argentina establishes a minimum oil price of US\$ 45/barrel for domestic sales, MercoPress. 20 May 2020. URL: https://en.mercopress.com/2020/05/20/argentina-establishes-a-minimum-oil-price-of-us-45-barrel-for-domesticsales (дата звернення: 21.07.2020)

4. COVID-19 in Latin America and the Caribbean: An overview of government responses to the crisis. URL: https://www.oecd.org/coronavirus/policy-responses/covid-19-in-latin-america-and-the-caribbean-an-overviewof-government-responses-to-the-crisis-0a2dee41/\#section-d1e207 (дата звернення: 21.07.2020)

5. Crucial election in oil rich Guyana; economy forecasted to grow 85\% this year, IMF, MercoPress. 2 March 2020. URL: https://en.mercopress.com/2020/03/02/crucial-election-in-oil-rich-guyana-economy-forecasted-to-grow-85-thisyear-imf (дата звернення: 21.07.2020)

6. Cunningham N. Argentina's Failing Fracking Experiment, NACLA Reporting on the Americas. 29 April 2020. URL: https://nacla.org/news/2020/04/29/vaca-muerta-argentina-fracking (дата звернення: 31.07.2020)

7. Falklands' Sea Lion development delayed responding to oil market conditions, MercoPress. 9 April 2020. URL: https://en.mercopress.com/2020/04/09/falklands-sea-lion-development-delayed-responding-to-oil-marketconditions (дата звернення: 21.07.2020)

8. Falklands' Sea Lion project: Rockhopper and Premier confident of farm out with US/Israel Navitas, MercoPress. 21 March 2020. URL: https://en.mercopress.com/2020/03/21/falklands-sea-lion-project-rockhopper-andpremier-confident-of-farm-out-with-us-israel-navitas (дата звернення: 21.07.2020)

9. Fiscal effects of coronavirus, oil could last years in Colombia - Fitch, Reuters. 23 June 2020.

URL: https://uk.reuters.com/article/colombia-ratings/fiscal-effects-of-coronavirus-oil-could-last-years-in-colombiafitch-idUKL1N2E01OJ (дата звернення: 25.06.2020)

10. Gamba L. China makes massive medical donation to Latin America, Anadolu Agency. 10.06.2020. URL: https://www.aa.com.tr/en/americas/china-makes-massive-medical-donations-to-latin-america/1871366 (дата звернення: 23.07.2020)

11. Iranian food ship docks in Venezuela.It is the latest example of cooperation between the two countries in the face of US opposition, AI-Monitor. URL: https://www.al-monitor.com/pulse/originals/2020/06/iran-sends-food-shipvenezuela.html\#ixzz6TIcmZpi6 (дата звернення: 23.07.2020)

12. Mexico has its oil protected by a sovereign hedge ensuring against low prices, MercoPress.13 April 2020. URL: https://en.mercopress.com/2020/04/13/mexico-has-its-oil-protected-by-a-sovereign-hedge-ensuring-againstlow-prices (дата звернення: 27.04.2020)

13. Parraga M. Venezuela's oil exports sink to 17-year low, choked by U.S. sanctions, Reuters. 2 June 2020. URL: https://www.reuters.com/article/us-venezuela-oil-exports/venezuelas-oil-exports-sink-to-17-year-low-chokedby-u-s-sanctions-idUSKBN2392SG (дата звернення: 27.07.2020)

14. Premier oil shelves $\$ 1.8 \mathrm{~B}$ Falkland Island offshore project, Oilandgaspeople.com. 14.05.2020.

URL: https://www.oilandgaspeople.com/news/story/premier-oil-shelves--1-8b-falkland-islands-offshore-project (дата звернення: 31.07.2020)

15. Rodrigo J. How should Colombia transform its oil-dependency for an eventual post COVID-19 global economic rebound? Trade Finance Global. 6 July 2020. URL: https://www.tradefinanceglobal.com/posts/how-shouldcolombia-transform-its-oil-dependency-for-an-eventual-post-covid-19-global-economic-rebound/ (дата звернення: 8.07.2020)

16. The World Factbook. URL: https://www.cia.gov/library/publications/the-world-factbook/rankorder/2242rank.html (дата звернення: 27.07.2020)

17. Venezuela announces the end of subsidized fuel prices together with privatized service stations, MercoPress. 1 June 2020. URL: https://en.mercopress.com/2020/06/01/venezuela-announces-the-end-of-subsidizedfuel-prices-together-with-privatized-service-stations (дата звернення: 27.07.2020)

18. Venezuela Crude Oil: Exports, CEIC. URL: https://www.ceicdata.com/en/indicator/venezuela/crude-oilexports (дата звернення: 31.07.2020) 
19. Williams I. 10 major South American upstream Oil \& Gas projects you need to know about.

URL: https://www.fircroft.com/blogs/10-major-south-american-upstream-oil-and-gas-projects-you-need-to92332116375 (дата звернення: 30.07.2020)

20. With oil royalties plummeting, Rio state challenged by investment funds, MercoPress. 24 April 2020.

URL: https://en.mercopress.com/2020/04/24/with-oil-royalties-plummeting-rio-state-challenged-by-investment-funds (дата звернення: 25.07.2020)

21. YPF slashes oil production 50\% as consumption slumps and depots are overflowing, MercoPress. 11 April 2020. URL: https://en.mercopress.com/2020/04/11/ypf-slashes-oil-production-50-as-consumption-slumps-and-depotsare-overflowing (дата звернення: 10.06.2020)

22. Zerpa F., Yapur N. Venezuela Considers Privatizing Gas Stations in Historic Shift, Bloomberg. 20 May 2020. URL: https://www.bloomberg.com/news/articles/2020-05-20/amid-gasoline-scarcity-and-pandemic-maduro-mullsprivate-pumps (дата звернення: 25.07.2020)

\section{References:}

1. Konopka N.O., Kostiv B.B. Problemy enerhetychnoi zalezhnosti derzhav Tsentralnoi Ameryky i Karybskoho baseinu, Politychne zhyttia. 2018. №2. S. 118-124. DOI 10.31558/2519-2949.2018.2.19

2. Stalo vidomo, na dopomohu yakym krainam pidut pershi $\$ 1,9$ mlrd Svitovoho banku, Mind.

URL: https://mind.ua/news/20209547-stalo-vidomo-na-dopomogu-yakim-krayinam-pidut-pershi-19-mlrd-svitovogobanku (Access date: 24.07.2020)

3. Argentina establishes a minimum oil price of US\$ 45/barrel for domestic sales, MercoPress. 20 May 2020. URL: https://en.mercopress.com/2020/05/20/argentina-establishes-a-minimum-oil-price-of-us-45-barrel-for-domesticsales (Access date: 21.07.2020)

4. COVID-19 in Latin America and the Caribbean: An overview of government responses to the crisis. URL: https://www.oecd.org/coronavirus/policy-responses/covid-19-in-latin-america-and-the-caribbean-an-overviewof-government-responses-to-the-crisis-0a2dee41/\#section-d1e207 (Access date: 21.07.2020)

5. Crucial election in oil rich Guyana; economy forecasted to grow $85 \%$ this year, IMF, MercoPress. 2 March 2020. URL: https://en.mercopress.com/2020/03/02/crucial-election-in-oil-rich-guyana-economy-forecasted-to-grow85-this-year-imf (Access date: 21.07.2020)

6. Cunningham N. Argentinas Failing Fracking Experiment, NACLA Reporting on the Americas. 29 April 2020. URL: https://nacla.org/news/2020/04/29/vaca-muerta-argentina-fracking (Access date: 31.07.2020)

7. Falklands Sea Lion development delayed responding to oil market conditions, MercoPress. 9 April 2020. URL: https://en.mercopress.com/2020/04/09/falklands-sea-lion-development-delayed-responding-to-oil-marketconditions (Access date: 21.07.2020)

8. Falklands Sea Lion project: Rockhopper and Premier confident of farm out with US/Israel Navitas, MercoPress. 21 March 2020. URL: https://en.mercopress.com/2020/03/21/falklands-sea-lion-project-rockhopper-andpremier-confident-of-farm-out-with-us-israel-navitas (Access date: 21.07.2020)

9. Fiscal effects of coronavirus, oil could last years in Colombia - Fitch, Reuters. 23 June 2020.

URL: https://uk.reuters.com/article/colombia-ratings/fiscal-effects-of-coronavirus-oil-could-last-years-in-colombiafitch-idUKL1N2E01OJ (Access date: 25.06.2020)

10. Gamba L. China makes massive medical donation to Latin America, Anadolu Agency. 10.06.2020. URL: https://www.aa.com.tr/en/americas/china-makes-massive-medical-donations-to-latin-america/1871366 (Access date: 23.07.2020)

11. Iranian food ship docks in Venezuela.It is the latest example of cooperation between the two countries in the face of US opposition, AI-Monitor. URL: https://www.al-monitor.com/pulse/originals/2020/06/iran-sends-food-shipvenezuela.html\#ixzz6TIcmZpi6 (Access date: 23.07.2020)

12. Mexico has its oil protected by a sovereign hedge ensuring against low prices, MercoPress. 13 April 2020. URL: https://en.mercopress.com/2020/04/13/mexico-has-its-oil-protected-by-a-sovereign-hedge-ensuring-againstlow-prices (Access date: 27.04.2020)

13. Parraga M. Venezuelas oil exports sink to 17-year low, choked by U.S. sanctions, Reuters. 2 June 2020. URL: https://www.reuters.com/article/us-venezuela-oil-exports/venezuelas-oil-exports-sink-to-17-year-low-chokedby-u-s-sanctions-idUSKBN2392SG (Access date: 27.07.2020)

14. Premier oil shelves \$1.8B Falkland Island offshore project, Oilandgaspeople.com. 14.05.2020.

URL: https://www.oilandgaspeople.com/news/story/premier-oil-shelves--1-8b-falkland-islands-offshore-project (Access date: 31.07.2020)

15. Rodrigo J. How should Colombia transform its oil-dependency for an eventual post COVID-19 global economic rebound? Trade Finance Global. 6 July 2020. URL: https://www.tradefinanceglobal.com/posts/how-shouldcolombia-transform-its-oil-dependency-for-an-eventual-post-covid-19-global-economic-rebound/ (Access date: 8.07.2020)

16. The World Factbook. URL: https://www.cia.gov/library/publications/the-world-factbook/rankorder/2242rank.html (Access date: 27.07.2020)

17. Venezuela announces the end of subsidized fuel prices together with privatized service stations, MercoPress.1 June 2020. URL: https://en.mercopress.com/2020/06/01/venezuela-announces-the-end-of-subsidizedfuel-prices-together-with-privatized-service-stations (Access date: 27.07.2020). 
18. Venezuela Crude Oil: Exports, SEIS. URL: https://www.ceicdata.com/en/indicator/venezuela/crude-oil-exports (Access date: 31.07.2020)

19. Williams I. 10 major South American upstream Oil \& Gas projects you need to know about.

URL: https://www.fircroft.com/blogs/10-major-south-american-upstream-oil-and-gas-projects-you-need-to-92332116375 (Access date: 30.07.2020)

20. With oil royalties plummeting, Rio state challenged by investment funds, MercoPress. 24 April 2020.

URL: https://en.mercopress.com/2020/04/24/with-oil-royalties-plummeting-rio-state-challenged-by-investment-funds (Access date: 25.07.2020)

21. YPF slashes oil production 50\% as consumption slumps and depots are overflowing, MercoPress. 11 April 2020. URL: https://en.mercopress.com/2020/04/11/ypf-slashes-oil-production-50-as-consumption-slumps-and-depots-areoverflowing (Access date: 10.06.2020)

22. Zerpa F., Yapur N. Venezuela Considers Privatizing Gas Stations in Historic Shift, Bloomberg. 20 May 2020. URL: https://www.bloomberg.com/news/articles/2020-05-20/amid-gasoline-scarcity-and-pandemic-maduro-mullsprivate-pumps (Access date: 25.07.2020)

Konopka N. O., Kostiv B. B. Energy market of Latin America countries in situation of pandemic: threats, protection mechanisms and potential impact

The COVID-19 pandemic has affected all countries of the world, and its consequences are tangible not only today, but will have effect in the long run. The article is devoted to the impact of the coronavirus crisis on the energy market in Latin America. The study identifies the main threats, outlines potential protection mechanisms, and attempts to predict the further development of the situation in the energy sector in times of crisis.

Mexico has begun to actively implement a number of protection mechanisms (hedging, redirection of state trust funds, etc.) to counter the effects of the coronavirus crisis. Argentina's police is similar, as the country has introduced a decree obliging oil companies to support production and investment at the level of 2019 in order to mitigate the impact of the crisis. Venezuela, as a country the most dependent on oil exports, is facing an acute shortage threat. They allowed to sell oil to private companies, which in turn put an end to the state's monopoly on the energy market. The oil price collapse has highlighted serious problems in the Colombian economy, which could last for several years.

Continuation or reintroduction of quarantine measures does not give hope for a rapid recovery in demand for oil and petroleum products, which threatens to reduce investment in the region. Therefore, governments are forced to seek financial support from international organizations or other states. It is noted that the pandemic has dealt a severe blow to countries that have lost potential opportunities and failed to reach a better economic level. In addition, difficulties have been encountered in implementation of large-scale projects in the field of oil production.

The authors conclude that most countries of the region will have to adapt to new realities and, as a result, make structural changes in national economies. As the COVID-19 pandemic is unlikely to end in the near future and compliance with quarantine measures remains relevant, it will be necessary to look for other ways of economic development that are not related to energy exports.

Key words: energy market, Latin America, COVID-19, Mexico, Argentina, Venezuela, Colombia, oil, economy, crisis. 